\begin{tabular}{|l|l|l||}
\hline \multicolumn{2}{|c|}{ PublisherInfo } \\
\hline \hline PublisherName & $:$ & BioMed Central \\
\hline \hline PublisherLocation & $:$ & London \\
\hline \hline PublisherImprintName & $:$ & BioMed Central \\
\hline \hline
\end{tabular}

\title{
Whither NHGRI?
}

\begin{tabular}{|l|l|l||}
\hline \multicolumn{2}{|c|}{ ArticleInfo } \\
\hline \hline ArticleID & $:$ & 4754 \\
\hline \hline ArticleDOI & $:$ & $10.1186 /$ gb-spotlight-20030417-02 \\
\hline \hline ArticleCitationID & $:$ & spotlight-20030417-02 \\
\hline \hline ArticleSequenceNumber & $:$ & 106 \\
\hline \hline ArticleCategory & $:$ & Research news \\
\hline ArticleFirstPage & $:$ & 1 \\
\hline \hline ArticleLastPage & $:$ & 4 \\
\hline \hline & & RegistrationDate : 2003-4-17 \\
\hline ArticleHistory & $:$ & OnlineDate \\
\hline ArticleCopyright & $:$ & BioMed Central Ltd2003-17 \\
\hline \hline ArticleGrants & $:$ & \\
\hline \hline ArticleContext & $:$ & 130594411 \\
\hline \hline
\end{tabular}


Having accomplished what it was created for, the National Human Genome Research Institute (NHGRI) is not about to declare victory and quietly disband. Its To Do list, published in the April 17 Nature, should keep it in business for decades.

NHGRI's central achievement, of course, has been coordinating the massive international project to map and sequence the human genome. The project is not completely finished, and perhaps it can't be. But, with a sequence declared on Monday to be $99 \%$ accurate, it's close enough for government work especially government work that came in ahead of schedule (2003, not 2005) and under budget (the US spent $\$ 2.7$ billion, not a projected $\$ 3$ billion), as NHGRI director Francis Collins is fond of pointing out.

"It's certainly one of the most successful initiatives that the National Institutes of Health has begun in the last decade. That's true from any objective criterion: the number of papers published, the impact of the papers, the standing of the investigators in the field," said top cancer geneticist Bert Vogelstein of Johns Hopkins University, who chaired the advisory board of NHGRI's in-house research program during its early years.

Genome sequencing will remain central to the agency's mission, but it is already mounting ambitious new projects and adopting a new philosophy. "We see a broader landscape of opportunities in this next phase," Collins told us. "That involves understanding the biology of the genome, but much more intentionally moving toward medical benefits."

Potentially the most far-reaching project is ENCODE(the ENCyclopedia Of DNA Elements). ENCODE is to be nothing less than a catalog of all the functional elements in the genome, genes and otherwise - what Collins calls a "parts list." It will start small, focusing on a target region of $30 \mathrm{Mb}$, which is about $1 \%$ of the human genome. Researchers will develop, test, and compare high-throughput methods of zeroing in on functional elements; the 3-year budget is $\$ 36$ million.

ENCODE is to be fully operational in the fall. "How long will it take us to figure out, with this combination of experimental and computational approaches, how to find all of the functional elements in this carefully chosen one percent of the genome?" said Collins. "I would hope in a couple of years we'd know an awful lot about how to do this. But I don't know, because this is new territory."

Some researchers are delighted about venturing into this new territory. San Ming Wang, who does gene expression studies in Janet Rowley's lab at the University Chicago, is one of them. Wang has grumbled that researchers are moving too quickly to proteomics, leaving undone a vast amount of work on genomes already sequenced. He likes ENCODE because it aims to identify all transcription units in the human genome. "I think NHGRI is in the right direction in guiding the future genome studies," Wang said. "This is just the beginning, not the end."

Collins is particularly excited about another NHGRI initiative: the plan to use small molecules to develop probes for the human genome's proteins and pathways. "Those become very powerful probes for biology, but they are also the first step in finding a lead compound that would have therapeutic benefit. This is the bread-and-butter of the pharmaceutical industry, but most academic investigators have never had the chance to take advantage of this and are rather unfamiliar with it. Some of us believe 
the time has come to have this kind of technology more widely available," said Collins. The strategy might also result in compounds that could be licensed to pharmas and moved into clinical trials.

This is one way NHGRI is pushing grantees toward practical medical applications of their work. "Our institute has traditionally been more involved in a basic science orientation, but I think we are intending to move more in a clinical direction," Collins said. Much of this would be in partnership with other institutions, inside NIH and elsewhere, and perhaps private companies. NHGRI's new 5-year plan published by Nature this week speaks of a renewed interest in rare genetic diseases and also emphasizes a need for more knowledge about the genetics of health rather than the genetics of disease. Collins noted, "There's no institute at NIH that focuses on what it is that keeps us healthy, nor is there in our medical care system much of a focus on those people who aren't getting sick. We'd like to understand that better."

Ethical, legal, and social issues have been saddled with the unfortunate acronym ELSI, providing an inevitable source of jokes about NHGRI's ELSI program serving as a cash cow for bioethics. The quips are wry but apt: the original allocation of 3\% of NHGRI's budget has been upped to $5 \%$, with spending totaling $\$ 125$ million in the past 13 years.

"We clearly need to continue this in the most vigorous way," Collins told us. But NHGRI will be more assertive in steering ELSI grantees toward specific subjects, he said. "We're going to shift our emphasis more in the direction of topics that we know we need people to work on. We're also considering funding centers for ELSI research, as opposed to individual investigators." The point is to develop institutions with a critical mass of different disciplines.

The head of the first bioethics think tank, the Hastings Center, agrees that daunting bioethics work lies ahead. On Thomas Murray's list are quagmire topicssuch as what genome research can and should mean in the developing world and intellectual property issues that range from ownership of genes and tissues to free and open access to researchers' genome data.

Murray told us, "There will be new issues that are not going to be taken care of by the generally feckless privacy laws we have right now and the equally feckless genetic antidiscrimination laws we have now. And some of the issues that have been around for 10 to 15 years are going to get more acute and take new forms. They will be quantitatively different, and that sometimes means qualitatively different."

\section{References}


1. National Human Genome Research Institute, [http://www.genome.gov]

2. Powledge T: Human genome project completed. Genome Biol, April 15, 2003. [http://genomebiology.com/researchnews/default.asp?arx_id=gb-spotlight-20030415-01]

3. Pray L: Post-genome project launches. Genome Biol, March 6, 2003., [http://genomebiology.com/ researchnews/default.asp?arx_id=gb-spotlight-20030306-01]

4. "What's Next? Turning Genomics Vision into Reality," NHGRI press release, April 14, 2003., [http://www.genome.gov/11006944]

5. ELSI Research Program, [http://www.genome.gov/10001618]

6. Brickley P: Sobriety amid the celebration. Genome Biol, April 14, 2003., [http://genomebiology.com/ researchnews/default.asp?arx_id=gb-spotlight-20030414-02] 